\title{
A nyálmirigydaganatok epidemiológiája világszerte
}

\author{
Irodalmi áttekintés
}

\author{
NÉMETH VIOLA*, DR. NÉMETH ZSOLT**, DR. UJPÁL MÁRTA**
}

\begin{abstract}
A nyálmirigydaganatok nem sorolhatók a gyakori tumoros megbetegedések közé. Valószínűleg éppen ezért előfordulásukat tekintve világszerte viszonylag kevés szakirodalmi adat áll rendelkezésünkre. Cikkünkben igyekeztünk ezeket a tanulmányokat úgy összegyújteni a különböző kontinensekröl, hogy egy összefoglaló, releváns képet kaphassunk epidemiológiájukról. Kutatásunkhoz a PubMeden kerestünk publikációkat 1998 és 2018 között, és a kapott eredményeket rendszereztük. A benignus daganatok magasabb arányban, átlagosan 65,6\%-ban fordultak elő, a malignusak 34,4\%-ban, kivéve Nigériát és Iránt. Itt a malignus daganatok voltak gyakoribbak. Az átlagos életkor 46,8 év, Európában az 50-es, egyéb kontinenseken a 40-es korosztály érintett. A nemek közötti megoszlásban kiegyenlítettség található, kivéve Mexikót, Kamerunt és Teheránt, ahol jelentős a női dominancia. A legtöbb tumor a parotisban lokalizálódott, a leggyakoribb jóindulatú tumor a pleomorph adenoma, míg a rosszindulatúak között az adenocysticus carcinoma és a mucoepidermoid carcinoma álltak az első helyen. A világ egyes országaiban észlelt eltérések egyrészt földrajzi, etnikai és szociális okokra, másrészt az egészségügyi adminisztráció, regisztráció különbözőségére vezethetők vissza. Az okok pontosabb feltárására további vizsgálatokra van szükség.
\end{abstract}

Kulcsszavak: benignus és malignus nyálmirigydaganatok, epidemiológia

\section{Bevezetés}

A nyálmirigydaganatok meglehetősen ritkán fordulnak elö, a fej-nyakdaganatok 3-6\%-át teszik ki [17], azonban ezek a daganatok szövettani besorolásukat tekintve széles skálát fednek le. Az Egészségügyi Világszervezet (WHO) 13 jóindulatú és 24 rosszindulatú entitást fogad el [3]. Lokalizációjukat tekintve sokkal gyakrabban, 80-85\%-ban fordulnak elő a nagy nyálmirigyekben, míg a kis nyálmirigyekben csupán $15-20 \%$-ban. A nagy nyálmirigytumorok mintegy $75-80 \%$-a benignus és ezek 85-90\%-a a parotisban található. A submandibularis mirigy daganatai teszik ki tulajdonképpen a maradék 5-10\%-ot, melyeknek körülbelül a fele rosszindulatú. A sublingualis mirigyelváltozások pedig rendkívül ritkák, és szinte egytől-egyig malignus eredetǔek. A kis nyálmirigyek esetén a jóindulatú daganatok aránya kisebb, csak 50-55\%. Köztük a legtöbb neoplasma a palatum mirigyeiben jelenik meg $[6,18]$. A nyálmirigydaganatok legfőbb tünetei a duzzanat és deformitás. A benignus daganatok elmozdíthatók, a malignus elváltozások rögzítettek, fájdalmasak, felettük a bőr kifekélyesedik [18]. Szövettani besorolás alapján a hám eredetú, benignus pleomorph adenoma (vegyes daganat) a leggyakoribb tumor. A benignus daganatok között az előfordulás gyakorisága szerint a Warthin-tumor (cystadenoma papillare lymphomatosum) a következő.
A mucoepidermoid carcinoma a leggyakoribb rosszindulatú daganat, míg a sorban szorosan utána következik az adenocysticus carcinoma [12].

\section{Vizsgálati anyag és módszer}

Szakirodalmi kutatásunkkal szeretnénk átfogó képet nyújtani a nyálmirigydaganatok világméretű epidemiológiájáról. A PubMed keresőjébe a „salivary gland tumor AND epidemiology" kulcsszavakat írtuk be. A találatokat 20 éves intervallumra szükítettük, 1998-2018-ig. Összesen 1327 találatot kaptunk. Kiválogattuk azon tanulmányokat, amelyek a nyálmirigydaganatok teljes spektrumával foglalkoztak, ez 30 cikket jelentett. Ezekből igyekeztünk kiválasztani azokat, amelyek a különböző kontinensekről származnak, szem előtt tartva a minél nagyobb populációk közötti diverzitást. Így végül 13 publikáció maradt, egy magyar, egy német és tizenegy angol nyelvű.

A tanulmányokból kigyűjtött adatokat többféle szempont alapján dolgoztuk fel. Megnéztük a benignus és malignus daganatok százalékos arányát, a nemek szerinti megoszlást. Összehasonlítottuk a daganattal diagnosztizált páciensek átlag életkorait, továbbá a tumorok lokalizációja közötti különbségeket az egyes régiók, országok között. Végül a leggyakoribb jó- és rosszindu- 
latú szövettani típusokat gyakoriság szerint is rangsoroltuk. Az eredményekről táblázatokat és diagramokat készítettünk.

\section{Eredmények}

A benignus és malignus nyálmirigydaganatok százalékos előfordulása 11 esetben hasonló, vagy szinte megegyezik az irodalmi $70-30 \%-o s$ átlaggal (1. ábra). Két esetben tér el ettől: Teheránban $35,3 \%$ a benignus és $64,7 \%$ a malignus tumorok aránya [20], Nigériában pedig 38 és $62 \%$-ról számoltak be [14].

A páciensek átlag életkorát tekintve egyértelmű különbség látható az európai országok és a többi kontinens országai között. Míg Európában az 50-es, addig Afrikában, Ázsiában és Dél-Amerikában 40-es korosztály a leginkább érintett. Sőt Afrikában, Kamerunban a nyálmirigydaganatos betegek átlagéletkora még ennél is alacsonyabb: 37,4 év [15] (2. ábra).

A nemek szerinti megoszlást vizsgálva azt tapasztaltuk, hogy a férfi-nő arány lényegében kiegyenlített a vizsgált régiók többségében. Ettől eltér Mexikó, Kamerun és Teherán, ahol a női túlsúly számottevő (3. ábra).

A nyálmirigydaganatok lokalizációjukat tekintve elsősorban a nagy nyálmirigyekben: parotisban, submandibularis és sublingualis mirigyben, illetve másodsorban a kis nyálmirigyekben találhatók. Szlovákiában volt a legmagasabb a tumorok aránya a parotisban, 83\% [16]. Ezt követi Németország 78,2\%-kal [10], majd Brazília 68, 5\%-kal [4]. Szorosan utána jön Horvátország $(65,3 \%)$ [9], és csupán Észak-Kína és Mexikó rendelkezik még $60 \%$ feletti adatokkal $(62,7$ és $64 \%)[5,11]$. Sorrendben ezután már csak Dél-Iránról (57,5\%) [7], Észak-Jordániáról (51\%) [1] és Kamerunról $(49,1 \%)$ [15] mondható el, hogy a daganatok többsége a parotisban helyezkedett el, de itt már nem számottevőek a különbségek a fültőmirigy javára. Teheránban (Irán) a legtöbb neoplasma (75\%-os arányban) a kis nyálmirigyekben volt [20]. Ez Nigériára és az Egyesült Királyságra is igaz, az afrikai országban a nyálmirigytumorok $73 \%$-a, míg a briteknél $61,8 \%$-uk volt megtalálható a kis nyálmirigyekben $[14 ; 8]$. A submandibularis mirigyben átlagosan a daganatok körülbelül 11\%-a helyezkedett el, kivétel Kamerun, ahol ennek csaknem 4-szerese: 39,6\% [15]. A sublingualis mirigyben elenyésző számban lokalizálódtak neoplasmák (1. táblázat). Egy 2005-ös magyar közlemény szerint a benignus daganatok $66,1 \%$-a a parotisban helyezkedett el, míg a többi csökkenő tendenciával a submandibularis, sublingualis és kis nyálmirigyekben. A malignus daganatok többsége a palatum kis nyálmirigyeiben volt megtalálható, ezután a legtöbb a sublingualis mirigyben, a legkevesebb pedig a submandibularis mirigyben és parotisban [19].

A szövettani leletet illetően a pleomorph adenoma volt egyértelmüen a leggyakoribb daganat mind a jóindulatú tumorok között, mind az összes tumor tekintetében. A dél-amerikai országokban, Brazíliában és Mexikóban volt a legmagasabb az arány: 67,8, ill. 65,6\% [4, 11]. Dél-Iránban, Észak-Jordániában és Szlovákiában szinte ugyanazok az 54\% körüli eredmények születtek. Ez a hasonlóság ugyancsak elmondható Kamerunról (47,7\%) [15], Horvátországról $(47,2 \%)$ [9], az Egyesült Királyságról $(44,4 \%)$ [8] és Észak-Kínáról $(42,6 \%)$ [5]. Sorrendben az utolsó helyekre Nigéria, Teherán és Németország kerül, 33; 32,6 és 30,2\%-kal, de még így is a pleomorph adenoma volt a leggyakoribb tumor ezeken a területeken $[10,14,20]$. A második helyen a Warthin-tumor állt, kivéve az Egyesült Királyságban, Nigériában és Teheránban. Harmadik leggyakoribb, benignus szövettani típusként előfordultak még a különféle monomorph adenomák, illetve myoepitheliomák.

A malignus nyálmirigydaganatoknál már nem volt ilyen kifejezett dominancia egyik entitás tekintetében sem. Azonban így is elmondható, hogy mindegyik országban a leggyakoribb rosszindulatú tumor az adenocysticus carcinoma és a mucoepidermoid carcinoma volt (4. ábra).

A nyálmirigydaganatok lokalizációja országonként

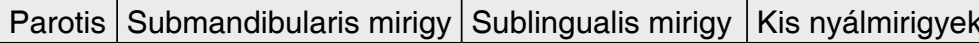

\begin{tabular}{|l|l|c|c|c|}
\hline & Parotis & Submandibularis mirigy & Sublingualis mirigy & Kis nyálmirigyek \\
\hline Németország & $78,2 \%$ & $7 \%$ & $0,8 \%$ & $14 \%$ \\
\hline Szlovákia & $83 \%$ & $10,8 \%$ & $3,2 \%$ & $3 \%$ \\
\hline UK & $31,4 \%$ & $5,2 \%$ & $1,6 \%$ & $61,8 \%$ \\
\hline Horvátország & $65,3 \%$ & $6,6 \%$ & $0,9 \%$ & $27,2 \%$ \\
\hline Brazília* & $68,5 \%$ & $15,5 \%$ & nem volt & $14,5 \%$ \\
\hline É-Kína & $62,7 \%$ & $9,9 \%$ & $2,6 \%$ & $24,8 \%$ \\
\hline Nigéria & $16 \%$ & $9 \%$ & $2 \%$ & $73 \%$ \\
\hline Irán, Teherán** & $14,7 \%$ & $4,3 \%$ & $1,7 \%$ & $75 \%$ \\
\hline D-Irán & $57,5 \%$ & $13,2 \%$ & $0,8 \%$ & $28,5 \%$ \\
\hline É-Jordánia & $51 \%$ & $20,6 \%$ & $n e m$ volt & $28,4 \%$ \\
\hline Mexikó & $64 \%$ & $16,8 \%$ & $0,3 \%$ & $18,9 \%$ \\
\hline Kamerun & $49,1 \%$ & $39,6 \%$ & $0,4 \%$ & $10,9 \%$ \\
\hline
\end{tabular}

* nem meghatározott lokalizáció: 1,5\%, ** intraossealis lokalizáció: 4,3\% 


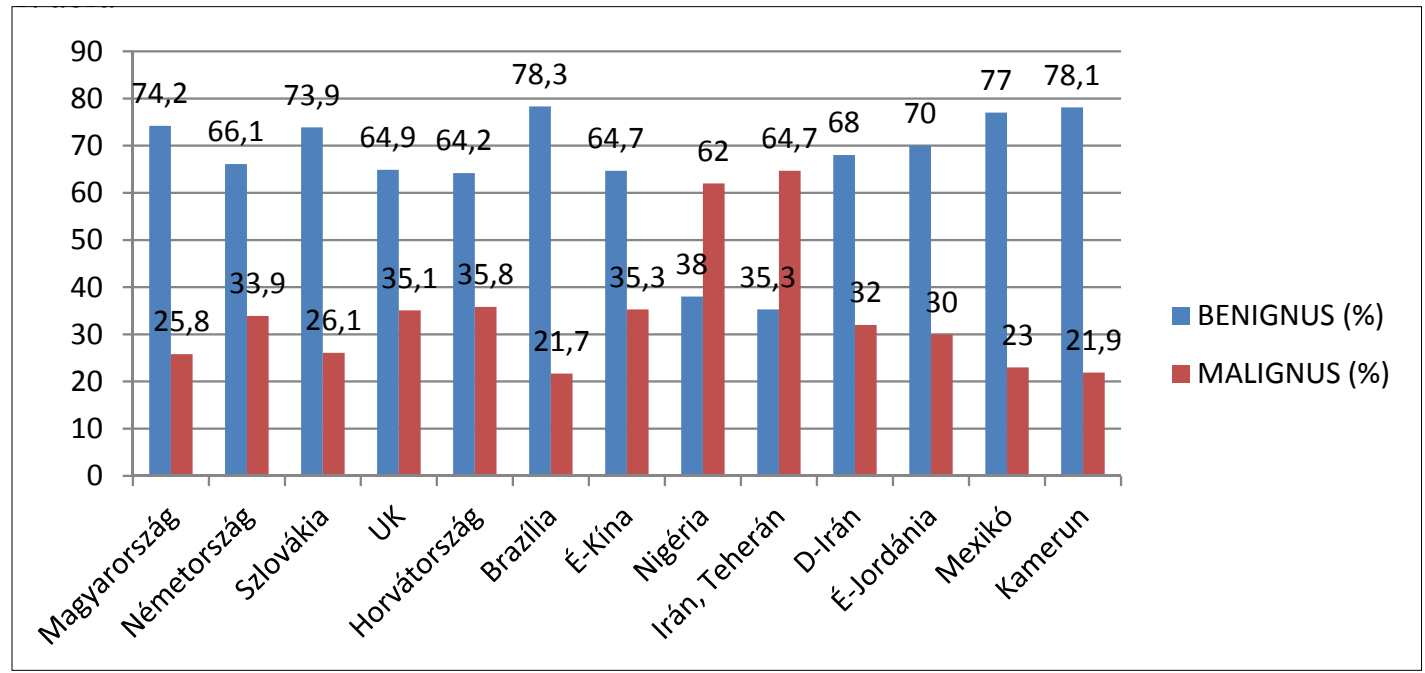

1. ábra: A jó- és rosszindulatú nyálmirigydaganatok százalékos megoszlása a világ különböző országaiban

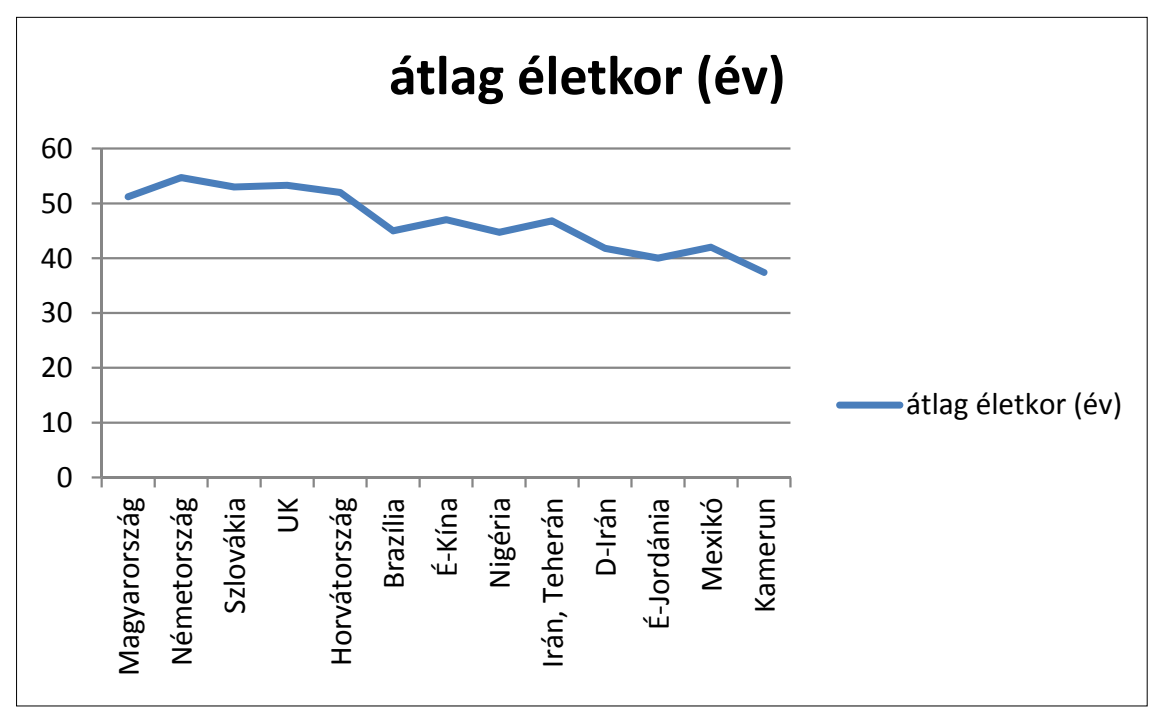

2. ábra: A nyálmirigydaganatos páciensek átlag életkorának megoszlása

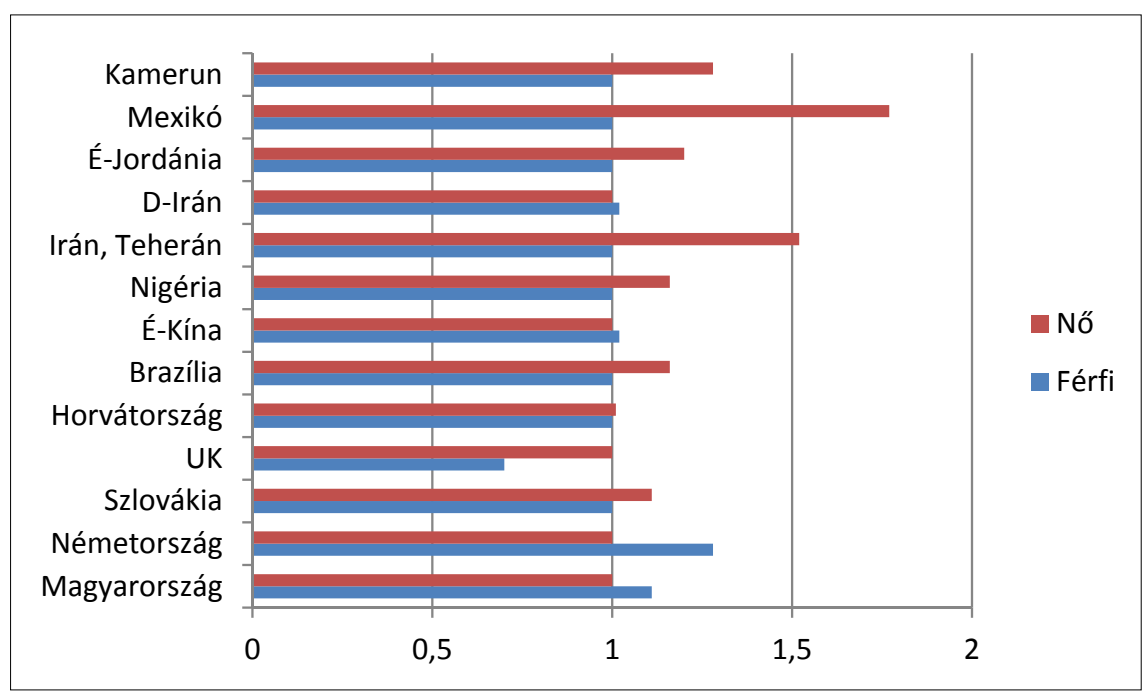

3. ábra: A nyálmirigydaganatok nemek közötti megoszlása 


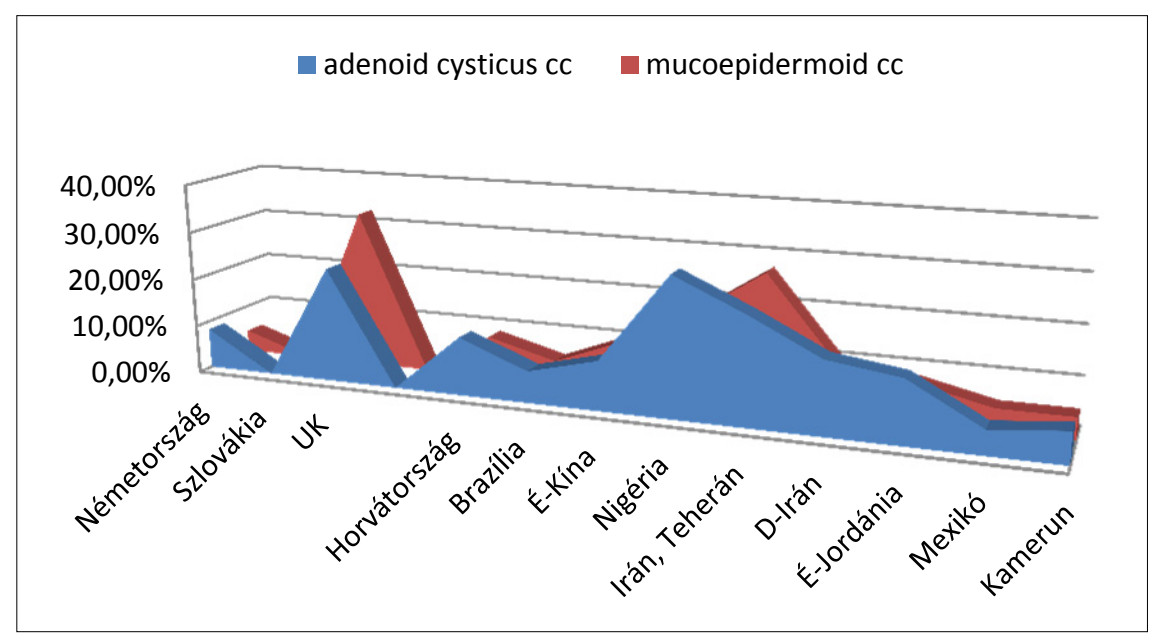

4. ábra: Adenocysticus és mucoepidermoid carcinoma megoszlása területenként

\section{Megbeszélés}

A nyálmirigydaganatok etiológiája nagyrészt ismeretlen. Általános prediszponáló tényezőként ismert az alacsony dózisú sugárzás [2, 17]. Felmerülhet hormonális és metabolikus tényezők oki szerepe is. A már korábban is említett, 2005-ös magyar tanulmány vizsgálta a metabolikus szindróma és a primer nyálmirigytumorok közötti összefüggést. Megállapították, hogy szignifikánsan magasabb volt a metabolikus szindrómában és diabetesben szenvedők aránya a nyálmirigytumoros betegek körében, mint a kontrollcsoportban [19].

A jó- és rosszindulatú daganatok aránya Nigériában és Teheránban tolódott el a malignitás irányába. A nigériai tanulmány szerint ennek oka az országon belüli, régiók közötti társadalmi-gazdasági különbség lehet [14]. Egy másik észak-nigériai összefoglaló szerint az afrikai kontinens és a nyugati világ eltérő epidemiológiai adatainak oka az, hogy a benignus tumorokat egyszerúen nem regisztrálják, illetcve a páciensek az alacsony morbiditású kórképekkel nem keresik fel az orvost [13]. A teheráni cikkben sem tudnak határozott magyarázatot adni az országon belüli eltérő eredményekre. A szerzők szerint ezek a különbségek a faji tényezőkből, a mintavétel patológiai központjainak különbözőségéből és az eltérő adminisztrációs precizitásból fakadhatnak. Erre utal az is, hogy a dél-iráni referátum összegzései egyeznek a nagy átlaggal. Ennek valószínüsíthető oka, hogy az adatgyüjtés a térség legnagyobb, maxillofaciális tumorokkal foglalkozó centrumában történt [20].

Lokalizációt tekintve egyértelmüen a parotis volt a leggyakrabban érintett mirigy, de itt is akadtak kivételek. Megint csak Nigériában és Teheránban alakultak másképp a százalékok. Mindkét régióban a legtöbb daganat a kisnyálmirigyekben fordult elő [14, 20]. Mindez összhangban is áll a ténnyel, miszerint a malignus tumorok jóval gyakrabban találhatók ezekben a mirigyekben. A harmadik kivétel az Egyesült Királyság. Egy sheffieldi patológiai centrum rögzítette az adatokat 31 évre visszamenőleg, 1974 és 2005 között. A szerzők szerint magyarázatként szolgálhat, hogy csak az utolsó 10-12 évben kaptak nagy nyálmirigyből származó mintákat, miután az orális és maxillofaciális sebészetet hivatalosan önálló szakterületként ismerték el [8].

A legalacsonyabb átlagéletkort Kamerunban regisztrálták. Ez könnyen érthetővé válik, ha megnézzük a születéskor várható élettartamot: 59 év nőknél és 57 év férfiaknál [21]. A nőknél gyakrabban fordul elő nyálmirigytumor ebben az országban. A cikk egy egyszerû magyarázatot ad erre: a nők igényesebbek külsejükre, egészségtudatosabbak, hamarabb orvoshoz fordulnak [15]. Ez a tendencia Mexikó esetében is megfigyelhető, ahol a női páciensek harmadik és ötödik évtizedeiben jelennek meg ezek az elváltozások. A jóindulatú epitheliális daganatok voltak a leggyakoribbak náluk. A fiatalabb korosztályokban azonban inkább roszszindulatú daganatokat találtak, tehát a mexikói populációban a nyálmirigy adenocarcinoma demográfiai profilja eltér a többitől. Ennek az egyértelmű okát még nem tárták fel [11].

Összefoglalva megállapíthatjuk, hogy a nyálmirigydaganatok a fej-nyak tumorok változatos fejezetét képezik, etiológiájuk szerteágazó, a mai napig nem tisztázott. A világ egyes országaiban észlelt eltérések egyrészt földrajzi, etnikai és szociális okokra, másrészt az egészségügyi adminisztráció, regisztráció különbözőségére vezethetők vissza.

\section{Irodalom}

1. Al-Khateeb TH, Ababneh KT: Salivary tumors in north Jordanians: a descriptive study. Oral Surg Oral Med Oral Pathol Oral Radiol Endod 2007; 103 (5): e53-59. https://doi.org/10.1353/tj.2007.0069

2. Andersson L, Kahnberg KE, Pogrel MA: Oral and Maxillofacial Surgery. Wiley-Blackwell, Hoboken, 2010; 761

3. Barnes L, Eveson JW, Reichart P, Sidransky D: World Health Organization Classification of Tumours: Pathology and Genetics of Head and Neck Tumours. IARC Press, Lyon, 2005; 210. 
4. de Oliveira FA, Duarte EC, Taveira CT, Máximo AA, de Aquino EC, Alencar Rde C, et al: Salivary Gland Tumor: A Review of 599 Cases in a Brazilian Population. Head Neck Pathol 2009; 3 (4): 271-275. https://doi.org/10.1007/s12105-009-0139-9

5. Gao M, Hao Y, Huang MX, Ma DQ, Chen Y, Luo HY, et al: Salivary gland tumours in a northern Chinese population: a 50-year retrospective study of 7190 cases. Int J Oral Maxillofac Surg 2017; 46 (3): 343-349. https://doi.org/10.1016/j.ijom.2016.09.021

6. Hupp J, Tucker M, Ellis E: Contemporary Oral and Maxillofacial Surgery. (6th ed.) Elsevier Mosby, St. Louis, 2014; 415-419.

7. JaAfari-AshKaVAndi Z, Ashraf MJ, Moshaverinia M: Salivary gland tumors: a clinicopathologic study of 366 cases in southern Iran. Asian Pac J Cancer Prev 2013; 14 (1): 27-30. https://doi.org/10.7314/ APJCP.2013.14.1.27

8. Jones AV, Craig GT, Speight PM, Franklin CD: The range and demographics of salivary gland tumours diagnosed in a UK population. Oral Oncol 2008; 44 (4): 407-417. https://doi.org/10.1016/j. oraloncology.2007.05.010

9. Lukšić I, Virag M, ManoJlović S, Macan D: Salivary gland tumours: 25 years of experience from a single institution in Croatia. J Cranio-Maxillofacial Surg 2012; 40 (3): e75-e81. https://doi. org/10.1016/j.jcms.2011.05.002

10. Machtens E: Speicheldrüsenerkrankungen. Mund Kiefer GeschichtsChir 2000; 4 (1): 401-413. https://doi.org/10.1007/ PL00014564

11. Mejía-Velázquez CP, Durán-Padilla MA, Gómez-Apo E, QuezadaRivera D, Gaitán-Cepeda LA: Tumors of the salivary gland in Mexicans. A retrospective study of 360 cases. Med Oral Patol Oral Cir Bucal 2012; 17 (2): e183-189. https://doi.org/10.4317/ medoral. 17434
12. Miloro M, Ghali GE, Larsen PE, Waite PD: Peterson's Principles of oral and maxillofacial surgery. (2nd ed.) BC Decker, London, 2004; 671-677.

13. Ochicha O, Malami S, Mohammed A, Atanda A: A histopathologic study of salivary gland tumors in Kano, northern Nigeria. Indian J Pathol Microbiol 2009; 52: 473-476. https://doi.org/10.4103/03774929.56121

14. Omitola OG, Soyele OO, Butali A, Akinshipo AO, Окoh D, Sigbeku $O$, et al: Descriptive epidemiology of salivary gland neoplasms in Nigeria: An AOPRC multicenter tertiary hospital study. Oral Dis 2018; 25 (1): 142-149. https://doi.org/10.1111/odi.12956

15. Sando Z, Fokouo JV, Mebada AO, Djomou F, NDJolo A, OYono JL: Epidemiological and histopathological patterns of salivary gland tumors in Cameroon. Pan Afr Med J 2016; 23: 66. https://doi. org/10.11604/pamj.2016.23.66.5105

16. SATKo I, Stanko P, Longauerová I: Salivary gland tumours treated in the stomatological clinics in Bratislava. J Craniomaxillofac Surg 2000; 28 (1): 56-61. https://doi.org/10.1054/jcms.1999.0092

17. Shah J, Patel S, Singh B: Jatin Shah's Head and Neck Surgery and Oncology. (4th ed.) Elsevier, Philadelphia, 2012; 526-528.

18. SuBA Zs: Orális és maxillofaciális patológia. Medicina, Budapest, 2011; 365-367.

19. Suba Zs, Barabás J, TaKÁcs D, Szabó Gy, UJPÁl M: Az inzulinrezisztencia és a nyálmirigydaganatok epidemiológiai összefüggései. Orv Hetil 2005; 146 (33): 1727-1732. https://doi.org/10.2307/ 25434163

20. Taghavi N, Sargolzaei S, Mashhadiabbas F, Akbarzadeh A, KarDOUNI P: Salivary gland tumors: a 15-year report from Iran. Turkish J Pathol 2015; 32 (1): 35-39. https://doi.org/10.5146/tjpath.2015.01336 21. https://www.who.int/countries/cmr/en/ (2019.05.08.)

\section{Review}

NÉMETH V, NÉmEth Zs, UJPÁL M

\section{The worldwide epidemiology of salivary gland tumors}

Salivary gland tumors cannot be classified as frequent tumors. That is why worldwide we have relatively only a limited number of publications on their occurrence. In our article, we tried to collect these studies from different continents so that we could get a concise, relevant picture of their epidemiology. For our research, we have looked for publications in PubMed between 1998 and 2018 and we systematized the results. Benign tumors occurred at a higher rate, on average $65,6 \%, 34,4 \%$ of malignancies, except Nigeria and Iran, where malignant tumors were more common. The average age is 46,8 years, in Europe the age group of $50 \mathrm{~s}$, on other continents the age group of $40 \mathrm{~s}$ is more concerned. The gender distribution is equal, except in Mexico, Cameroon and Tehran, where female dominance is significant. Most tumors were localized in the parotid, the most common benign tumor was pleomorphic adenoma, while adenocystic carcinoma and mucoepidermoid carcinoma ranked first among malignants. Differences in countries around the world can be attributed to geographical, ethnic and social reasons, and to differences in health administration and registration. Further investigations are needed to identify the causes more accurately.

Keywords: benign and malignant salivary gland tumors, epidemiology 